\title{
Synonymy of Flavobacterium pectinovorum Dorey with Cytophaga johnsonae Stanier
}

\author{
PENELOPE CHRISTENSEN ${ }^{1}$ \\ Department of Soil Science, University of Alberta, Edmonton, Alberta, Canada
}

\begin{abstract}
Several authors have suggested that Flavobacterium pectinovorum Dorey 1959 should be removed from the genus Flavobacterium and that it might be a Cytophaga species. An extensive study of the morphological, physiological, biochemical, and antimicrobial lytic properties of the holotypic strain NCIB 9059 (ATCC 19366) of $F$. pectinovorum has revealed that it is more properly classified as Cytophaga johnsonae Stanier 1947. The guanine-plus-cytosine ratio of 33 mol\% agrees with the range reported for $C$. johnsonae ( 30 to $35 \mathrm{~mol} \%$ ).
\end{abstract}

The pectolytic Flavobacterium pectinovorum Dorey 1959 was originally isolated from soil in southeast England and studied for its ability to produce polygalacturonase (8). The name is validly published and legitimate (33), and the holotypic reference culture is NCIB 9059 (ATCC 19366), which is Dorey's isolate no. 81. This is also the only readily available culture. $F$. pectinovorum NCIB 9059 is an orange-yellow-pigmented, gram-negative, aflagellate rod which exhibits gliding motility $(17,18,23)$, although spreading on agar media has not been evident in previous work $(18,21,23)$. It has been suggested that this species be reassigned to Brisou's yellow, nonmotile genus Empedobacter (5; P. Kaiser, Ph.D. Thesis, University of Paris, Paris, France, 1971), but the consensus is that this organism more properly belongs in the genus Cytophaga $(17,18,21,32)$. No formal proposal to assign the species to a different genus and no study establishing synonymy with an established Cytophaga species have yet been made.

\section{MATERIALS AND METHODS}

Materials. The holotypic culture of $F$. pectinovorum NCIB 9059 (ATCC 19366) was compared in the tests described below with nine Cytophaga johnsonae cultures (Table 1).

Methods. The standard medium used for growing these organisms was skim acetate (SA) agar or broth (7), and incubation was at $25^{\circ} \mathrm{C}$ unless otherwise stated.

\section{MORPHOLOGY}

Cell morphology. The dimensions, motility, and arrangement of the cells were determined from living preparations examined at $1,000 \times$ magnification from 1-day-old SA broth cultures. Gram stains were performed on 1- and 8-day-old SA broth cultures and on 2-day-old SA plate cultures (Table 2).

\footnotetext{
${ }^{1}$ Present address: Department of Microbiology, Univer-
} sity of Alberta, Edmonton, Alberta, T6G 2E1, Canada.

\section{CULTURAL CHARACTERISTICS}

Colony morphology. Descriptions of colony form, elevation, Munsell colour $(6,22)$, and of optical, surface, and edge characteristics (26) were made from single colonies grown on 2-day-old Cook's cytophaga agar (7), plate count agar (Difco), and SA plates for 5 days. Colours were compared using light from a window with northern exposure during the morning or afternoon. The presence of any watersoluble pigment and spreading ability was noted on all plates used in this study (Table 3).

Growth in liquid media. Observation of the silkiness of a culture when gently shaken and of flexing movement by individual cells was made every day for 12 days on cultures grown in unshaken SA broth tubes.

\section{PHYSIOLOGY}

Salt tolerance. The dried surfaces of four SA plates made up with $0,1,2$, and $3 \% \mathrm{NaCl}$, respectively, were inoculated with a central streak of the test organism in that order so that no carry-over of $\mathrm{NaCl}$ would occur. The amounts of growth, spreading, and lysis were noted at 14 days (Table 4, columns 2 and 3 ).

Atmospheric conditions for growth. SA plates were inoculated with a single, central streak of the test organism and incubated under three different atmospheres. The first group was in air, the second was in a candle jar (about $10 \% \mathrm{O}_{2}$ ), and the third was under hydrogen and carbon dioxide in a Gas-Pak jar (BBL, Becton, Dickinson, and Co., Cockeysville, Md.). At 7 days, estimates of the amount of growth and lysis were made (Table 4, columns 4 and 5).

Temperature limits for growth. Replicate SA streak plates were incubated at temperatures ranging from 0 to $50^{\circ} \mathrm{C}$ for 6 days, at which time the type and relative width of growth were recorded. The $0^{\circ} \mathrm{C}$ plates were incubated for 10 days, and those at $35^{\circ} \mathrm{C}$ or more were wrapped in polythene bags to prevent excess moisture loss (Table 4, columns 6 and 7).

pH range for growth. Batches of SA agar were adjusted with $\mathrm{HCl}$ or $\mathrm{NaOH}$ to different $\mathrm{pH}$ levels before autoclaving and were rechecked afterwards. When the surfaces had dried, the plates were inocu- 
TABLE 1. Origin and designation of strains used in this study

\begin{tabular}{|c|c|c|}
\hline Strain no. ${ }^{a}$ & Species & Source \\
\hline UASM 4432 & Actinomycete & F. D. Cook, from soil \\
\hline UASM 4441 & Actinomycete & F. D. Cook, from soil \\
\hline UASM 4165 & Arthrobacter sp. & $\begin{array}{l}\text { F. D. Cook, from Prairie Regional Lab, Saskatoon, } \\
\text { Saskatchewan, Canada }\end{array}$ \\
\hline \multirow[t]{2}{*}{ UASM 4611} & Bacillus subtilis & $\begin{array}{l}\text { F. D. Cook, from Prairie Regional Lab, Saskatoon, } \\
\text { Saskatchewan, Canada }\end{array}$ \\
\hline & Chlorella sp. & Department of Botany, Univ. of Alberta \\
\hline Stanier 6 & Cytophaga hutchinsonii & R. Y. Stanier \\
\hline NCIB 10782 & C. hutchinsonii & NCIB, from N. Palleroni \\
\hline ATCC 17061 & C. johnsonae & ATCC, from C. B. van Niel \\
\hline UASM 405 & C. johnsonae & F. D. Cook, from soil, Ottawa, Ontario, Canada \\
\hline UASM ALF & C. johnsonae & $\begin{array}{l}\text { F. D. Cook, from alfalfa roots, Edmonton, Alberta, } \\
\text { Canada }\end{array}$ \\
\hline UASM B-2-25 & C. johnsonae & $\begin{array}{l}\text { D. C. Gillespie, from diseased freshwater fish, Man- } \\
\text { itoba, Canada }\end{array}$ \\
\hline UASM E-1-25 & C. johnsonae & $\begin{array}{l}\text { D. C. Gillespie, from diseased freshwater fish, Man- } \\
\text { itoba, Canada }\end{array}$ \\
\hline UASM 4433 & C. johnsonae & F. D. Cook, from moose dung, Alberta, Canada \\
\hline UASM 4539 & C. johnsonae & F. D. Cook, from moose dung, Alberta Canada \\
\hline UASM 3 & C. johnsonae & F. D. Cook, from soil, Alberta, Canada \\
\hline UASM 4707 & C. johnsonae & F. D. Cook, from soil, Alberta, Canada \\
\hline UASM PC20 & Escherichia coli & $\begin{array}{l}\text { P. Christensen, from creek water, Edmonton, Al- } \\
\text { berta, Canada }\end{array}$ \\
\hline NCIB 9059 & $\begin{array}{l}\text { Flavobacterium pectinovorum } \\
\text { Penicillium notatum }\end{array}$ & $\begin{array}{l}\text { NCIB, from J. J. Dorey, from soil, S. E. England } \\
\text { N. Colotelo, Edmonton, Canada }\end{array}$ \\
\hline \multirow[t]{2}{*}{ ATCC 9027} & $\begin{array}{l}\text { Pseudomonas aeruginosa } \\
\text { Rhizopus sp. } \\
\text { Sclerotinia sclerotiorum } \\
\text { Serratia marcescens }\end{array}$ & $\begin{array}{l}\text { ATCC, from C. P. Hegarty, from ear infection } \\
\text { N. Colotelo, Edmonton, Canada } \\
\text { N. Colotelo, Edmonton, Canada } \\
\text { Provincial Laboratory of Public Health, Edmonton, } \\
\quad \text { Canada }\end{array}$ \\
\hline & $\begin{array}{l}\text { Yeast (probably Saccharomyces } \\
\text { cerevisiae) }\end{array}$ & $\begin{array}{l}\text { Fleischmann's fast-rising active dry yeast, Standard } \\
\text { Brands, Ltd., Montreal, Canada }\end{array}$ \\
\hline
\end{tabular}

a UASM, University of Alberta Soil Microbiology Laboratory, Edmonton, Alberta, Canada. UASM 405 = ATCC 29583; UASM ALF = ATCC 29584; UASM B-2-25 = ATCC 29585; UASM E-1-25 = ATCC 29586; UASM $4433=$ ATCC 29587; UASM $4539=$ ATCC 29588; UASM 3 = ATCC 29589; and UASM $4707=$ ATCC 29590 .

TABLE 2. Dimensions of Cytophaga johnsonae strains and of Flavobacterium pectinovorum NCIB 9059 in liquid culture after $24 h$ of incubation

\begin{tabular}{lcc}
\hline \multicolumn{1}{c}{ Strain } & Length $(\mu \mathrm{m})$ & Width $(\mu \mathrm{m})$ \\
\hline C. johnsonae & & \\
ATCC 17061 & $2-36$ & 0.2 \\
UASM 405 & $3-20$ & 0.4 \\
UASM ALF & $3-25$ & 0.2 \\
UASM B-2-25 & $3-20$ & 0.4 \\
UASM E-1-25 & $3-15$ & 0.5 \\
UASM 4433 & $3-12$ & 0.4 \\
UASM 4539 & $3-20$ & 0.5 \\
UASM 3 & $3-25$ & 0.3 \\
UASM 4707 & $3-20$ & 0.4 \\
F. pectinovorum & & \\
NCIB 9059 & $1-25$ & 0.3 \\
\hline
\end{tabular}

lated with spots of different test organisms, four per plate, on $\mathrm{pH} 5.0,6.0,7.0,8.0,9.0$, and 10.0 agar. Growth was estimated on a comparative basis after 5 days and on the range of $\mathrm{pH}$ values at which growth was initially recorded (Table 4, column 8 ).

Nitrogen sources for growth: (i) Nitrate. Salts- glucose agar plates were made with Hutchinson and Clayton salt solution (12) $\left(0.25 \% \quad \mathrm{NaNO}_{3}, 0.1 \%\right.$ $\mathrm{K}_{2} \mathrm{HPO}_{4}, 0.03 \% \mathrm{MgSO}_{4} \cdot 7 \mathrm{H}_{2} \mathrm{O}, 0.01 \% \mathrm{CaCl}_{2}$ [anhydrous], $0.01 \% \mathrm{FeCl}_{3}, \mathrm{pH} 7.2$ to 7.3 ) to which was added $0.1 \%$ (wt/vol) filter-sterilized glucose and $1.5 \%$ agar. A duplicate set of plates was made with the addition of $0.05 \%$ yeast extract. Streak inoculations were made and readings were taken at 9 days (Table 5, columns 2 and 3 ).

(ii) Ammonia. Board and Holding medium without the yeast extract was used, and lowering of the $\mathrm{pH}$ due to the utilization of ammonia was noted at 17 days by observing a change from blue to yellow in the colour of the medium (Table 5, column 4).

(iii) Urea. The medium was made up of two parts. Solution A consisted of $1 \mathrm{~g}$ of $\mathrm{K}_{2} \mathrm{HPO}_{4}, 0.2 \mathrm{~g}$ of $\mathrm{MgSO}_{4} \cdot 7 \mathrm{H}_{2} \mathrm{O}, 0.1 \mathrm{~g}$ of $\mathrm{CaCl}_{2}$ (anhydrous), $0.1 \mathrm{~g}$ of $\mathrm{NaCl}, 0.01 \mathrm{~g}$ of $\mathrm{FeCl}_{3}$, and $15 \mathrm{~g}$ of agar in $900 \mathrm{ml}$ of distilled water, adjusted to $\mathrm{pH} 6.8$ to 7.0 and autoclaved. Solution B contained $20 \mathrm{~g}$ of urea, $5 \mathrm{~g}$ of glucose, and $10 \mathrm{ml}$ of a $2 \%$ bromothymol blue solution in $90 \mathrm{ml}$ of distilled water, and was filter-sterilized before being added to the cooled solution $\mathrm{A}$ prior to pouring plates. Growth and elevation of $\mathrm{pH}$ as a result of ammonia production upon breakdown 
TABLE 3. Colony morphology of Cytophaga johnsonae strains and Flavobacterium pectinovorum NCIB 9059 after 5 days of incubation

\begin{tabular}{|c|c|c|c|c|c|c|c|}
\hline Agar & Strain & Form & Surface & Edge & Elevation & $\begin{array}{c}\text { Optical } \\
\text { properties }\end{array}$ & Colour $^{a}$ \\
\hline \multirow[t]{2}{*}{$\begin{array}{l}\text { Cook's cyto- } \\
\text { phaga agar }\end{array}$} & $\begin{array}{l}\text { C. johnsonae } \\
\text { ATCC } 17061 \\
\text { UASM } 405 \\
7 \text { others }^{b}\end{array}$ & $\begin{array}{l}\text { Irregular } \\
\text { Irregular } \\
\text { Irregular }\end{array}$ & $\begin{array}{l}\text { Rough } \\
\text { Rough } \\
\text { Rough or } \\
\text { smooth }\end{array}$ & $\begin{array}{l}\text { Erose } \\
\text { Undulate } \\
\text { Entire, lobate } \\
\quad \text { or erose }\end{array}$ & $\begin{array}{l}\text { Effuse } \\
\text { Effuse } \\
\text { Effuse or raised }\end{array}$ & $\begin{array}{l}\text { Transparent } \\
\text { Transparent } \\
\text { Transparent or } \\
\text { translucent }\end{array}$ & $\begin{array}{l}1.5 \text { YR } 7 / 10 \\
10 \text { YR } 7 / 10 \\
7.5 \text { YR } 6 / 10 \\
10 \text { YR } 6 / 10-12\end{array}$ \\
\hline & $\begin{array}{l}F \cdot \text { pectinovorum } \\
\text { NCIB } 9059\end{array}$ & Irregular & Rough & Undulate & Flat & Transparent & $10 \mathrm{YR} 7 / 10$ \\
\hline \multirow[t]{2}{*}{ Skim acetate } & $\begin{array}{l}\text { C. johnsonae } \\
\text { ATCC } 17061 \\
\text { UASM } 405 \\
7 \text { others }^{b}\end{array}$ & $\begin{array}{l}\text { Irregular } \\
\text { Irregular } \\
\text { Irregular }\end{array}$ & $\begin{array}{l}\text { Rough } \\
\text { Rough } \\
\text { Rough }\end{array}$ & $\begin{array}{l}\text { Erose/lobate } \\
\text { Lobate } \\
\text { Erose, lobate or } \\
\quad \text { undulate }\end{array}$ & $\begin{array}{l}\text { Effuse } \\
\text { Effuse } \\
\text { Effuse, umbon- } \\
\text { ate, or raised }\end{array}$ & $\begin{array}{l}\text { Translucent } \\
\text { Transparent } \\
\text { Transparent or } \\
\quad \text { translucent }\end{array}$ & $\begin{array}{l}5 \text { YR } 5 / 10 \\
10 \text { YR 6/8 } \\
5 \text { YR 5.5-6/10, } \\
7.5 \text { YR } 6 / 8-10 \text { or } \\
7 / 8-9\end{array}$ \\
\hline & $\begin{array}{l}F . \text { pectinovorum } \\
\text { NCIB } 9059\end{array}$ & Irregular & Rough & Erose & Effuse & & 2.5 YR 4/12 \\
\hline \multirow[t]{2}{*}{$\begin{array}{l}\text { Plate count } \\
\text { agar }\end{array}$} & $\begin{array}{l}C . \text { johnsonae } \\
\text { ATCC } 17061 \\
\text { UASM } 405 \\
7 \text { others }^{b}\end{array}$ & $\begin{array}{l}\text { Irregular } \\
\text { Irregular } \\
\text { Irregular or cir- } \\
\quad \text { cular }\end{array}$ & $\begin{array}{l}\text { Rough/smooth } \\
\text { Rough } \\
\text { Smooth or } \\
\text { rough }\end{array}$ & $\begin{array}{l}\text { Erose } \\
\text { Lobate } \\
\text { Entire or undu- } \\
\quad \text { late }\end{array}$ & $\begin{array}{l}\text { Effuse/convex } \\
\text { Effuse } \\
\text { Raised, convex, } \\
\text { umbonate, or } \\
\text { flat }\end{array}$ & $\begin{array}{l}\text { Translucent } \\
\text { Transparent } \\
\text { Translucent or } \\
\text { opaque }\end{array}$ & $\begin{array}{l}2.5 \text { YR } 4 / 10 \\
7.5 \text { YR } 5 / 8 \\
7.5 \text { YR } 5 / 6-10 \text { or } \\
6 / 10 \text { or } \\
9 \text { YR } 6 / 8\end{array}$ \\
\hline & $\begin{array}{l}F . \text { pectinovorum } \\
\text { NCIB } 9059\end{array}$ & $\begin{array}{l}\text { Roughly circu- } \\
\text { lar }\end{array}$ & Rough & Erose & Convex & Translucent & 5 YR 5/10 \\
\hline
\end{tabular}


TABLE 4. Physiology of Cytophaga johnsonae strains and Flavobacterium pectinovorum NCIB 9059. $I$.

\begin{tabular}{|c|c|c|c|c|c|c|c|}
\hline \multirow{3}{*}{ Strain } & \multicolumn{2}{|c|}{$\begin{array}{c}\mathrm{NaCl} \text { causing inhi- } \\
\text { bition }(\%)\end{array}$} & \multicolumn{2}{|c|}{ Atmospheric conditions for: } & \multicolumn{2}{|c|}{ Growth temp $\left({ }^{\circ} \mathrm{C}\right)$} & \multirow{2}{*}{$\begin{array}{l}\text { pH at which } \\
\text { growth is in- } \\
\text { itiated }\end{array}$} \\
\hline & Partial & $\begin{array}{l}\text { Com- } \\
\text { plete }\end{array}$ & Best growth & $\begin{array}{l}\text { Best lysis of } \\
\text { milk }\end{array}$ & Range & Optimum & \\
\hline & \multicolumn{2}{|c|}{$14^{a}$} & \multicolumn{2}{|c|}{7} & \multicolumn{2}{|c|}{$6\left(10\right.$ for $\left.0^{\circ} \mathrm{C}\right)$} & 5 \\
\hline \multicolumn{8}{|l|}{ C. johnsonae } \\
\hline ATCC 17061 & 2 & 3 & $10 \% \mathrm{O}_{2}$ & $10 \% \mathrm{O}_{2}$ & $10-35$ & 30 & $7-10$ \\
\hline UASM 405 & 1 & 2 & $10 \% \mathrm{O}_{2}$ & $10 \% \mathrm{O}_{2}$ & $8-35$ & 18 & $5-10$ \\
\hline UASM ALF & $1-2$ & 2 & $10 \% \mathrm{O}_{2}$ & Air & $0-30$ & $20-25$ & $5-10$ \\
\hline USAM B-2-25 & 1 & 3 & $10 \% \mathrm{O}_{2}$ & $10 \% \mathrm{O}_{2}$ & $0-30$ & 18 & $5-10$ \\
\hline UASM E-1-25 & 1 & 2 & $10 \% \mathrm{O}_{2}$ & $10 \% \mathrm{O}_{2}$ & $0-30$ & 20 & $5-10$ \\
\hline UASM 4433 & 1 & 3 & $10 \% \mathrm{O}_{2}$ & $10 \% \mathrm{O}_{2}$ & $0-30$ & 18 & $5-10$ \\
\hline UASM 4539 & 1 & 3 & $10 \% \mathrm{O}_{2}$ & $10 \% \mathrm{O}_{2}$ & $0-30$ & $18-20$ & $5-10$ \\
\hline UASM 3 & 1 & 2 & $10 \% \mathrm{O}_{2}$ & $10 \% \mathrm{O}_{2}$ & $0-35$ & 30 & $5-10$ \\
\hline UASM 4707 & 1 & 2 & $10 \% \mathrm{O}_{2}$ & $10 \% \mathrm{O}_{2}$ & $0-30$ & $18-25$ & $5-10$ \\
\hline \multicolumn{8}{|l|}{$F$. pectinovorum } \\
\hline NCIB 9059 & 1 & 3 & $10 \% \mathrm{O}_{2}$ & $10 \% \mathrm{O}_{2}$ & $0-30$ & $18-20$ & $5-10$ \\
\hline Column no. & 2 & 3 & 4 & 5 & 6 & 7 & 8 \\
\hline
\end{tabular}

a Days incubated.

of urea from streak inoculations were recorded at 20 days (Table 5, column 5).

(iv) Amino acids. Hutchinson and Clayton salts medium minus the $\mathrm{NaNO}_{3}$ was supplemented with either $0.1 \%$ monosodium glutamate or $0.1 \%$ sodium asparaginate, and gelled with $1.5 \%$ agar. A filtersterilized glucose solution was added to the cooled, autoclaved medium to a final concentration of $0.1 \%$. Growth of the spot inocula, four per plate, was noted at 9 days (Table 5, columns 6 and 7).

Growth factors: Stimulation by yeast extract. The results from two sets of tests were compared: (i) salts + glucose \pm yeast extract (see nitrate method above and Table 5, columns 2 and 3 ); (ii) chitin \pm yeast extract (see chitin method below and Table 8, columns 14 and 15).

Antibiotic and antibacterial sensitivities: (i) SLS. Streak inoculations were made on three groups of SA agar plates containing $0,0.01$, and $0.1 \%$ sodium lauryl sulfate (SLS), respectively (7). Growth with SLS was compared with that on the control plate at 5 days (Table 6 , columns 2 and 3 ).

(ii) Chloramphenicol, dihydrostreptomycin, penicillin, and polymyxin $\mathbf{B}$. A sufficient amount of an 18-h mid-logarithmic-phase SA broth culture of a test organism was spread with a bent glass rod on the surface of an SA plate to form confluent growth. After the surface of the plate had dried, disks (BBL) of four antibiotics of the following concentrations were placed firmly on the agar: chloramphenicol, 30 $\mu \mathrm{g}$; dihydrostreptomycin, $10 \mu \mathrm{g}$; penicillin $\mathrm{G}, 10$ units; and polymyxin B, 300 units. The diameters of growth inhibition were noted after 2 days and scored by the Kirby-Bauer scheme (2) (Table 6, columns 48 ).

(iii) Actinomycin D. Four sets of disks were made containing $0.1,1.0,10$, and $40 \mu \mathrm{g}$ of actinomycin D per disk respectively. These were placed on the dried surfaces of SA plates previously inoculated with the test bacteria as in the previous method. The results were read at 2 days (Table 6, column 9).

(iv) Nitrite. Growth in aerobic Penassay broth tubes (Difco antibiotic medium 3 ) containing $0.1 \%$ $\mathrm{KNO}_{2}$ was compared at 11 days with that in plain Penassay broth tubes to see if nitrite inhibition had taken place (Table 6, column 10).

Antimicrobial lytic action: (i) Bacteria. A selection of five bacterial species, Escherichia coli, Pseudomonas aeruginosa, Arthrobacter sp., Serratia marcescens, and Bacillus subtilis (Table 1), was used to screen the lytic activity of the test cultures against bacteria. Tests were made in a manner similar to antibiotic disk sensitivity tests, using 1 drop of an overnight SA shaken culture of the "predator" on a lawn of the "prey" organism. Two sets of plate count plates were used for each prey bacterium, the lawns being allowed to grow for $1 \mathrm{~h}$ and 2 days, respectively, before inoculation with potentially lytic test organisms. After 11 days, growth of the predators and lysis of the prey were determined (Table 7, columns 2 to 6 ).

(ii) Fungi, actinomycetes, and an alga. The lysis of autoclaved yeast cells was examined on yeast cell agar plates (7). The test cultures were streaked down the centre of a plate and, after 9 days, the growth of the cultures and their lytic action were noted (Table 7, column 12).

The lytic spectrum of the test cultures was estimated on the fungi Penicillium notatum, Rhizopus sp., and Sclerotinia sclerotiorum, two actinomycetes, UASM 4432 which produces a brown watersoluble pigment, and UASM 4441, which does not, and on the green alga Chlorella sp. (Table 1). These organisms were grown on plate count agar and were tested in the same manner as the bacteria. However, these prey organisms were allowed to grow for 1 and 4 days, respectively ( 2 weeks for Chlorella), before drops of the potential predator broth cultures were added (Table 7, columns 7 to 11 and 13).

\section{BIOCHEMICAL REACTIONS}

Oxidation-fermentation test. Poured tubes of Board and Holding medium (4) $0.5 \%$ filter-steri- 
TABLE 5. Physiology II. Nitrogen sources for Cytophaga johnsonae strains and Flavobacterium pectinovorum NCIB 9059

\begin{tabular}{|c|c|c|c|c|c|c|}
\hline \multirow{3}{*}{ Strain } & \multicolumn{6}{|c|}{ Nitrogen source ${ }^{a}$} \\
\hline & $\mathrm{NO}_{3}^{-}$ & $\begin{array}{c}\mathrm{NO}_{3}^{-}+ \\
\text {yeast extract }\end{array}$ & $\mathrm{NH}_{4}^{+}$ & Urea & Glutamate & $\begin{array}{c}\text { Asparagin- } \\
\text { ate }\end{array}$ \\
\hline & & $9^{b}$ & 17 & 20 & 9 & 9 \\
\hline \multicolumn{7}{|l|}{ C. johnsonae } \\
\hline ATCC 17061 & \pm & + & + & + & + & + \\
\hline UASM 405 & - & ++ & + & - & + & + \\
\hline UASM ALF & + & + & + & + & + & + \\
\hline UASM B-2-25 & + & $+t$ & + & - & + & + \\
\hline UASM E-1-25 & + & ++ & + & - & + & + \\
\hline UASM 4433 & + & ++ & + & - & + & + \\
\hline UASM 4539 & ++ & ++ & + & - & + & + \\
\hline UASM 3 & ++ & $+t$ & + & - & + & + \\
\hline UASM 4707 & ++ & ++ & + & - & + & + \\
\hline \multicolumn{7}{|l|}{$F$. pectinovorum } \\
\hline NCIB 9059 & ++ & ++ & + & + & + & + \\
\hline Column no. & 2 & 3 & 4 & 5 & 6 & 7 \\
\hline
\end{tabular}

a Scoring for columns 2 and $3:-$, none; \pm , weak; + , good; ++ , excellent; for column $4:+$, utilization of $\mathrm{NH}^{+}{ }_{4}$ shown by both growth and lowered $\mathrm{pH},-$, neither present; for column $5:+$, both growth and high $\mathrm{pH}$, due to release of $\mathrm{NH}_{3}$; -, neither present; for columns 6 and 7: +, growth; -, no growth.

${ }^{b}$ Days incubated.

TABLE 6. Physiology III. Sensitivities of Cytophaga johnsonae strains and Flavobacterium pectinovorum NCIB 9059 to antibacterial agents ${ }^{a}$

\begin{tabular}{|c|c|c|c|c|c|c|c|c|c|}
\hline \multirow{2}{*}{ Strain } & \multicolumn{2}{|c|}{$\begin{array}{l}\text { \% Sodium lauryl } \\
\text { sulfate at which } \\
\text { growth is: }\end{array}$} & \multirow{2}{*}{$\begin{array}{l}\text { Chlor- } \\
\text { amphen- } \\
\text { icol (30 } \\
\mu \mathrm{g})\end{array}$} & \multirow{2}{*}{$\begin{array}{l}\text { Strepto- } \\
\text { mycin } \\
(10 \mu \mathrm{g})\end{array}$} & \multirow{2}{*}{$\begin{array}{l}\text { Penicil- } \\
\text { lin G (10 } \\
\text { units) }\end{array}$} & \multicolumn{2}{|c|}{$\begin{array}{c}\text { Polymyxin B (300 } \\
\text { units) }\end{array}$} & \multirow{2}{*}{$\begin{array}{l}\text { Actino- } \\
\text { mycin D }\end{array}$} & \multirow{2}{*}{$\begin{array}{l}0.1 \% \\
\mathrm{NO}_{2}\end{array}$} \\
\hline & Reduced & Inhibited & & & & $\begin{array}{l}\text { Kirby- } \\
\text { Bauer }\end{array}$ & $\begin{array}{l}\text { Author's } \\
\text { scheme }\end{array}$ & & \\
\hline \multicolumn{10}{|l|}{ C. johnsonae } \\
\hline ATCC 17061 & 0.01 & 0.1 & $\mathbf{S}$ & I & $\mathbf{R}$ & $\mathbf{R}$ & I & $\mathbf{S}$ & $\mathbf{R}$ \\
\hline UASM 405 & 0.01 & 0.1 & $\mathbf{R}$ & I & $\mathrm{R}$ & $\mathrm{R}$ & $\mathbf{R}$ & $\overline{\mathbf{S}}$ & $\mathrm{R}$ \\
\hline UASM ALF & 0.01 & 0.1 & $\mathrm{~S}$ & I & $\mathrm{R}$ & $\mathrm{R}$ & $\mathbf{R}$ & $\mathbf{S}$ & $\mathbf{R}$ \\
\hline UASM B-2-25 & 0.01 & 0.1 & $\mathbf{S}$ & $\mathbf{R}$ & $\mathrm{R}$ & $\mathrm{R}$ & $\mathrm{S}$ & $\mathbf{R}$ & $\mathrm{S}$ \\
\hline UASM E-1-25 & 0.01 & 0.1 & $\mathbf{S}$ & $\mathbf{R}$ & $\mathbf{R}$ & $\mathrm{R}$ & $\mathbf{S}$ & $\mathrm{S}$ & $\mathrm{S}$ \\
\hline UASM 4433 & 0.01 & 0.1 & $\mathrm{~S}$ & $\mathrm{R}$ & $\mathbf{R}$ & $\mathrm{R}$ & $\mathbf{S}$ & $\mathrm{S}$ & $\mathrm{S}$ \\
\hline UASM 4539 & 0.01 & 0.1 & $\mathrm{~S}$ & I & $\mathrm{R}$ & $\mathrm{R}$ & I & $\mathbf{S}$ & $\mathrm{S}$ \\
\hline UASM 3 & 0.01 & 0.1 & I & $\mathbf{S}$ & I & I & $\mathbf{S}$ & $\mathrm{S}$ & $\mathbf{R}$ \\
\hline UASM 4707 & 0.01 & 0.1 & $\mathbf{S}$ & I & $\mathbf{R}$ & $\mathbf{R}$ & $\mathbf{R}$ & $\mathbf{S}$ & $\mathbf{S}$ \\
\hline \multicolumn{10}{|l|}{$F$. pectinovorum } \\
\hline NCIB 9059 & 0.01 & $>0.1$ & I & I & $\mathrm{I}$ & $\mathbf{R}$ & I & $\mathbf{S}$ & $\mathbf{S}$ \\
\hline Column no. & 2 & 3 & 4 & 5 & 6 & 7 & 8 & 9 & 10 \\
\hline
\end{tabular}

${ }^{a}$ All read at 2 days except sodium lauryl sulfate (5 days) and $\mathrm{NO}^{-}$(11 days). Abbreviations: $\mathrm{S}$, sensitive; $\mathrm{I}$, intermediate; $\mathrm{R}$, resistant. Columns 4 to 7 are scored according to Kirby-Bauer scheme (2). Column 8 is scored on the author's scheme based on behaviour of control organisms $E$. coli, $P$. aeruginosa, Arthrobacter sp., $S$. marcescens, and $B$. subtilis (see Table 1). Column 9 is scored in comparison to control organisms $E$. coli and $B$. subtilis: $\mathrm{S}$, more sensitive than $E$. coli, but not as sensitive as $B$. subtilis; $\mathrm{R}$, same as or less sensitive than $E$. coli, i.e., resistant. Column 10: $R$ (resistance), indicated by growth in tube; $S$ (sensitivity), no growth.

lized glucose, $0.5 \%$ agar, $0.05 \% \mathrm{NH}_{4} \mathrm{H}_{2} \mathrm{PO}_{4}, 0.05 \%$ $\mathrm{K}_{2} \mathrm{HPO}_{4}, 0.05 \%$ yeast extract, $1.5 \mathrm{ml}$ of $2 \%$ bromothymol blue solution per litre, $\mathrm{pH}$ 7.2) were inoculated by stabbing with a thin wire. One set was sealed with about $1 \mathrm{~cm}$ of paraffin wax, and both were incubated for 15 days, when the colours of the test and control tubes were noted (Table 8, columns 2 and 3 ).

Acid production from sugars and alcohols. Five sets of aerobic tubes of Board and Holding medium were made, substituting $0.5 \%$ solutions of cellobiose, sucrose, lactose, glycerol, and mannitol, respec- 
TABLE 7. Physiology IV. Antimicrobial lytic action shown by Cytophaga johnsonae strains and by Flavobacterium pectinovorum NCIB $9059^{a}$

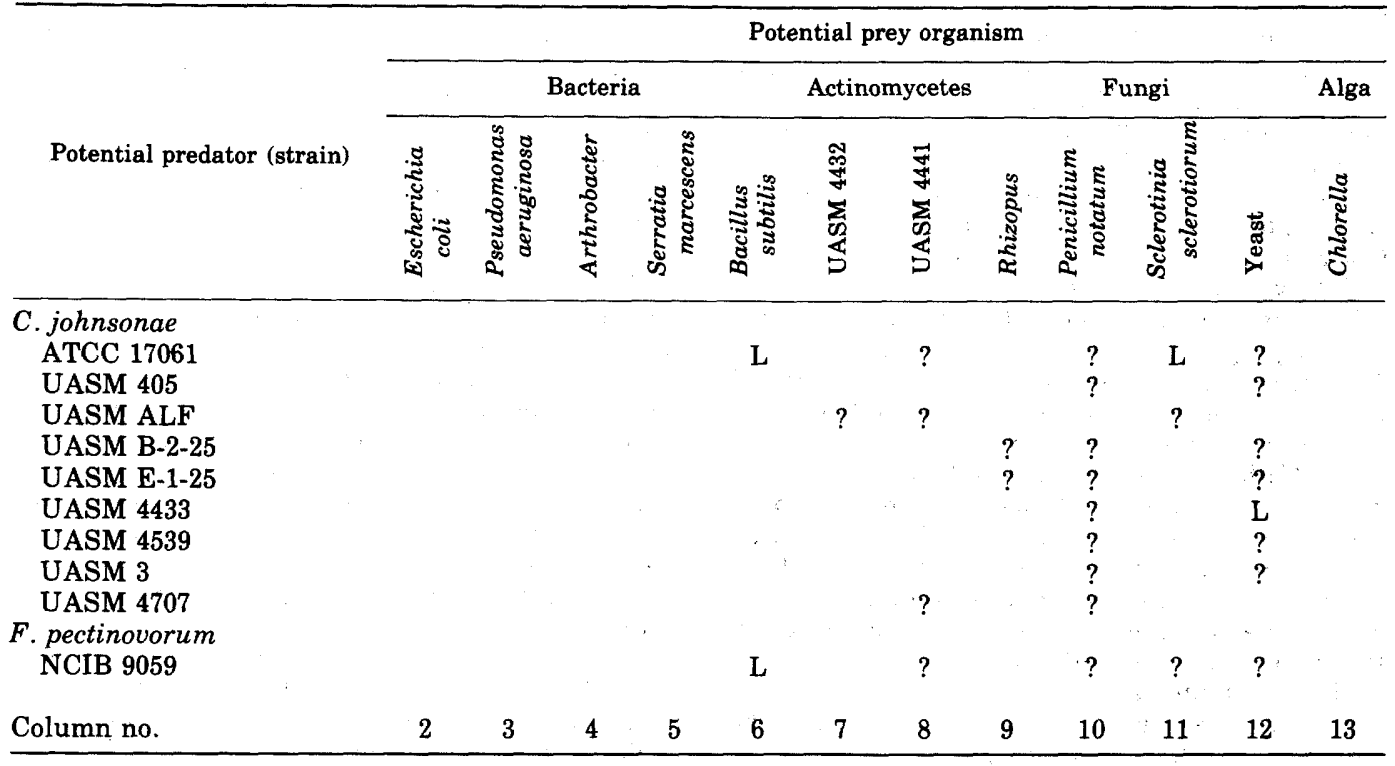

${ }^{a}$ Results read after 11 days, except yeast at 9 days. Maximum lytic activity in each test noted as: L, good lysis; ?, possible lysis; blank, no lysis.

TABLE 8. Biochemical reactions: Use of carbohydrates and polysaccharides by Cytophaga johnsonae strains and Flavobacterium pectinovorum NCIB $9059^{a}$

\begin{tabular}{|c|c|c|c|c|c|c|c|c|c|c|c|c|c|c|c|c|c|c|}
\hline \multirow{4}{*}{ Strain } & \multirow{2}{*}{\multicolumn{2}{|c|}{$\begin{array}{c}\text { O-F test } \\
\text { on glucose }\end{array}$}} & \multirow{2}{*}{\multicolumn{5}{|c|}{ Acid production from: }} & \multicolumn{11}{|c|}{ Hydrolysis of: } \\
\hline & & & & & & & & \multirow[b]{2}{*}{ 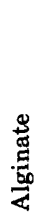 } & \multirow[b]{2}{*}{ 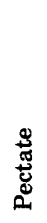 } & \multicolumn{2}{|c|}{ Cellulose } & \multicolumn{2}{|c|}{ Agar } & \multicolumn{2}{|c|}{ Chitin } & \multicolumn{3}{|c|}{ Starch } \\
\hline & 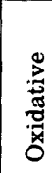 & 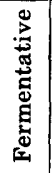 & 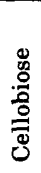 & 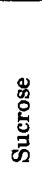 & 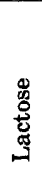 & 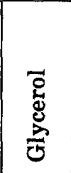 & 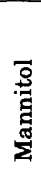 & & & $\sum_{j}^{0}$ & 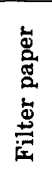 & 总 & 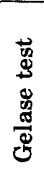 & $\underset{1}{2}$ & $\begin{array}{l}9 \\
+ \\
+\end{array}$ & $\underset{2}{2}$ & 告 & 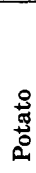 \\
\hline & \multicolumn{2}{|c|}{$15^{b}$} & \multicolumn{5}{|c|}{17} & \multicolumn{4}{|c|}{30} & 40 & 5 & \multicolumn{2}{|c|}{40} & 4 & 25 & 8 \\
\hline C. johnsonae & & & & & & & & & & & & & & & & & & \\
\hline ATCC 17061 & + & + & + & - & + & - & - & + & + & + & - & - & + & + & ++ & + & + & + \\
\hline UASM 405 & + & - & + & + & + & - & - & + & - & - & - & - & + & + & ++ & + & + & + \\
\hline UASM ALF & + & - & + & + & + & $\begin{array}{c}+ \\
\text { (slow) }\end{array}$ & + & - & + & + & - & - & + & ++ & ++ & + & + & + \\
\hline UASM B-2-25 & + & + & + & + & + & + & - & - & + & + & - & - & + & + & $t+$ & + & + & + \\
\hline UASM E-1-25 & + & + & + & + & + & + & - & - & + & + & - & - & + & + & ++ & + & + & + \\
\hline UASM 4433 & + & - & + & - & + & - & - & - & + & + & - & - & + & ++ & ++ & + & + & + \\
\hline UASM 4539 & + & - & + & + & + & - & - & - & + & - & 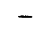 & - & + & + & ++ & + & + & + \\
\hline UASM 3 & + & - & + & + & + & - & - & - & + & + & - & - & + & + & ++ & + & + & + \\
\hline UASM 4707 & + & - & + & + & + & + & - & - & + & - & - & - & + & + & ++ & + & + & + \\
\hline F. pectinovorum & & & & & & & & & & & & & & & & & & \\
\hline NCIB 9059 & + & - & + & + & + & - & - & + & + & + & - & - & + & + & ++ & + & + & + \\
\hline Column no. & 1 & 2 & 3 & 4 & 5 & 6 & 7 & 8 & 9 & 10 & 11 & 12 & 13 & 14 & 15 & 16 & 17 & 18 \\
\hline
\end{tabular}

${ }^{a}$ Interpretation of symbols: Columns 1 to $7:+$, positive; - , negative; columns 8, 9, 10, and 12: +, liquefaction; - , no liquefaction; column 11: + , break of paper strip; -, paper strip intact; column 13: + , unstained gelase field left around colony; -, normal yellow colour; columns 14 and $15:++$, excellent; + , moderate; - , none; columns 16,17 , and 18: + , hydrolysis; -, no hydrolysis. Abbreviations: CMC, carboxymethyl cellulose; YE, yeast extract; SYS, salts-yeast extractstarch medium; NBS, nutrient broth-starch medium.

${ }^{b}$ Days incubated. 
tively, for the glucose. The colours of the test and control tubes were noted at 17 days (Table 8, columns 4-8).

Hydrolysis of polysaccharides: (i) Alginate, pectate, and CMC. Tubes of Hutchinson and Clayton salt solution with $0.05 \%$ yeast extract and $3 \%$ sodium alginate $(15,25), 3 \%$ sodium carboxymethyl cellulose (CMC) Fisher grade $7 \mathrm{HSP}(9,15)$, or $3 \%$ sodium polypectate (Nutritional Biochemicals Corp., Cleveland, Ohio) were inoculated with the test cultures. Estimates of liquefaction were made at intervals up to 1 month in the test and control tubes after cooling them at $10^{\circ} \mathrm{C}$ for $20 \mathrm{~min}$, when the sloppy gel in the control tubes had attained a firm consistency. Liquefaction was taken as evidence of alginase, CMCase, and polypectase activity, respectively (Table 8 , columns 9 to 11 ).

(ii) Cellulose. Strips of Whatman no. 1 filter paper $(1$ by $10 \mathrm{~cm})(20,28)$ were placed in SA broth tubes which were then inoculated. The control organism, Cytophaga hutchinsonii strains Stanier 6 and NCIB 10782, took about 12 days to break the paper strip at the air-water interface. Observations on the test organisms were made at intervals up to 30 days (Table 8, column 12).

(iii) Agar: (a) Agar + yeast extract tubes. Tubes of $1.5 \%$ agar (Difco) containing $0.05 \%$ yeast extract only were inoculated, and growth of the cultures and any softening of the agar were noted at intervals for 40 days (Table 8 , column 13 ). (b) Gelase field. The appearance of "gelase fields" around the colonies after flooding a plate with iodine is regarded by some workers as a reliable test for agar decomposition $(10,27,31)$. Inoculated SA plates incubated for 5 days were used in the present study (Table 8, column 14). All of these organisms showed a gelase field, but none showed softening or liquefaction of agar in tubes. The most likely explanation for this lack of correlation is that the organisms excrete some compound which interferes with the iodine reaction.

(iv) Chitin. Chitin agar was made with $40 \mathrm{ml}$ of a partially hydrolysed chitin suspension and $10 \mathrm{~g}$ of agar per litre of water $(11,16,24)$. This produces a slightly milky gel within which digestion of the chitin can be seen as a clear zone around the organism. A duplicate set of plates with $0.05 \%$ yeast extract added was also used. Inoculated plates were kept in a damp chamber for 40 days, and the growth and clearing were noted at intervals (Table 8, columns 15 and 16).

(v) Starch: (a) Salts-yeast extract-starch plates. Two percent "soluble" starch (Fisher), $0.05 \%$ yeast extract, and $1.0 \%$ agar were added to Hutchinson and Clayton salt solution (26). Streak-inoculated plates were incubated for 4 days when growth and hydrolysis (iodine reaction) (15) were noted (Table 8 , column 17).

(b) Nutrient broth-starch tubes. Two percent soluble starch (Fisher) was added to nutrient broth

TABLE 9. Biochemical reactions: Hydrolysis of proteins by Cytophaga johnsonae strains and Flavobacterium pectinovorum NCIB 9059

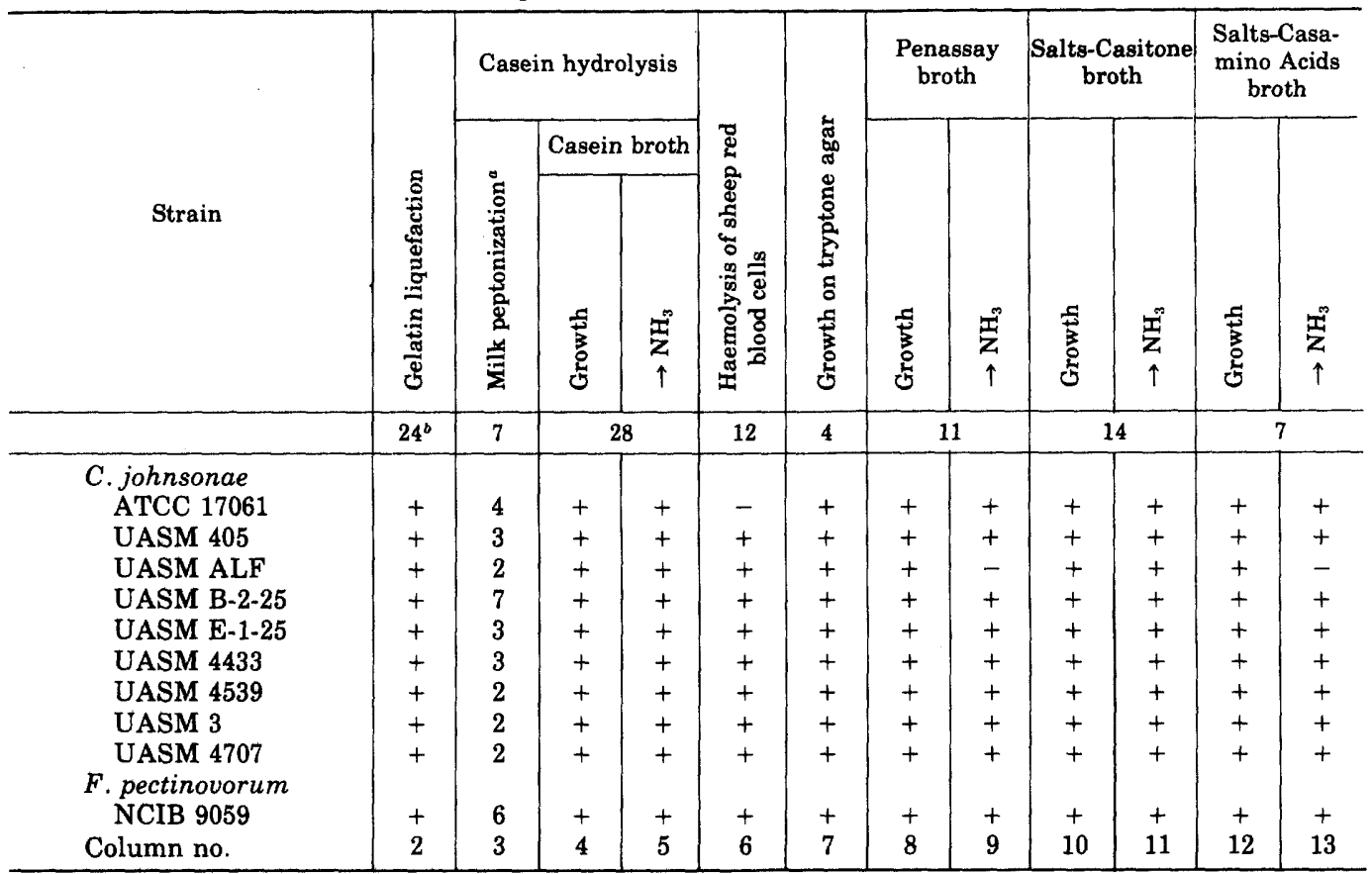

${ }^{a}$ Number of days for complete clearing.

${ }^{b}$ Days incubated. 
TABLE 10. Biochemical reactions of Cytophaga johnsonae strains and Flavobacterium pectinovorum NCIB $9059^{a}$

\begin{tabular}{|c|c|c|c|c|c|c|c|}
\hline \multirow{2}{*}{ Strain } & \multicolumn{5}{|c|}{ Production of: } & \multicolumn{2}{|c|}{$\begin{array}{l}\text { Reduction of } \mathrm{NO}_{3}^{-} \text {and } \\
\qquad \mathrm{NO}_{2}^{--}:\end{array}$} \\
\hline & $\mathrm{H}_{2} \mathrm{~S}$ & Indole $e^{b}$ & Catalase & Oxidase & $\begin{array}{c}\text { Phospha- } \\
\text { tase }\end{array}$ & $\begin{array}{c}\mathrm{NO}_{3}^{-} \rightarrow \\
\mathrm{NO}_{2}^{-}\end{array}$ & $\mathrm{NO}_{2}^{-} \rightarrow$ gas \\
\hline & $7^{\dot{c}}$ & $7-28$ & 5 & $<10 \mathrm{~s}$ & 4 & 11 & 11 \\
\hline \multicolumn{8}{|l|}{ C. johnsonae } \\
\hline ATCC 17061 & + & - & + & + & + & - & + \\
\hline UASM 405 & + & - & + & + & + & + & + \\
\hline UASM ALF & + & - & + & + & + & + & - \\
\hline UASM B-2-25 & + & - & + & + & + & + & - \\
\hline UASM E-1-25 & + & - & + & + & + & + & - \\
\hline UASM 4433 & + & - & + & + & + & + & - \\
\hline UASM 4539 & + & - & + & + & + & + & - \\
\hline UASM 3 & + & - & + & + & + & + & + \\
\hline UASM 4707 & + & - & + & + & + & + & - \\
\hline \multicolumn{8}{|l|}{$F \cdot$ pectinovorum } \\
\hline NCIB 9059 & + & - & + & + & + & + & - \\
\hline Column no. & 2 & 3 & 4 & 5 & 6 & 7 & 8 \\
\hline
\end{tabular}

${ }^{a}$ Interpretation of symbols: columns 2 to $6:+$, positive; - , negative; column $7:+$, no $\mathrm{NO}_{3}^{-}$present, no $\mathrm{NH}_{3}$ produced, neutral $\mathrm{pH}, \mathrm{NO}_{2}^{-}$produced; - , $\mathrm{NO}_{3}^{-}$still present; column $8:+$, no $\mathrm{NO}_{2}^{-}$present, no $\mathrm{NO}_{3}^{-}$ produced, no $\mathrm{NH}_{3}$ produced, neutral $\mathrm{pH}$, gas bubbles may be present; -, residual $\mathrm{NO}_{2}{ }^{-}$still present.

${ }^{b}$ The results for indole were negative for all four series of tests.

c Days incubated.

(Difco) solution (26). Growth, pH, and hydrolysis (iodine spot test) were recorded at 25 days (Table 8 , column 18).

(c) Potato starch. Potato infusion agar was made up as follows: mashed potato, $20 \%$; glucose, $0.5 \%$; agar, $1.5 \% ; \mathrm{CaCO}_{3}, 0.3 \% ;\left(\mathrm{NH}_{4}\right)_{2} \mathrm{SO}_{4}, 0.1 \%$. After 8 days, the hydrolysis of starch was noted using the iodine test (Table 8, column 19).

Hydrolysis of proteins: (i) Gelatin liquefaction. Tubes of $12 \%$ gelatin in water (26) were stab-inoculated and incubated for 24 days. Liquefaction was measured after cooling the tubes at $10^{\circ} \mathrm{C}$ for $1 \mathrm{~h}$ to set unaltered gelatin (Table 9 , column 2).

(ii) Casein: (a) In milk (peptonization). The number of days taken to clear SA broth and the presence or absence of a lytic zone around the culture when grown on SA agar were recorded (Table 9, column 3).

(b) In casein broth. Duplicate tubes containing only $0.5 \%$ casein (Fisher) were inoculated, and growth and ammonia production (Nessler reagent) were recorded at 28 days (Table 9 , columns 4 and 5 ).

Haemolysis. Sheep blood agar plates (26) were inoculated with the test cultures in a manner to produce single colonies. Growth and haemolysis were noted at 12 days (Table 9, column 6 ).

Production of ammonia and growth in: (i) SaltsCasitone broth. A medium containing 2.0\% Casitone (Difco), $0.2 \% \quad \mathrm{MgSO}_{4}, 0.1 \% \quad \mathrm{~K}_{2} \mathrm{HPO}_{4}$, and $0.06 \%$ $\mathrm{KH}_{2} \mathrm{PO}_{4}$ adjusted to $\mathrm{pH} 7.6$ was used. Observations on growth and ammonia production (Nessler reagent) were made at 14 days in duplicate tubes (Table 9, columns 10 and 11). (ii) Salts-Casamino Acids broth. A solution of $1.0 \%$ vitamin-free Casamino Acids (Difco), 0.1\% $\mathrm{K}_{2} \mathrm{HPO}_{4}, 0.05 \% \mathrm{KNO}_{3}, 0.02 \% \mathrm{MgSO}_{4}, 0.01 \% \mathrm{NaCl}$, and $0.001 \% \mathrm{FeCl}_{3}$ adjusted to $\mathrm{pH} 7.0$ to 7.1 was employed. Two tubes were inoculated with each organism, and growth and ammonia production (Nessler reagent) were recorded at 7 days (Table 9, columns 12 and 13 ).

(iii) Tryptone agar. Cultures were streaked on Cook's cytophaga agar $(0.2 \%$ tryptone, $1 \%$ agar; 7$)$ and incubated for 4 days, when the presence or absence of growth was observed (Table 9, column 7).

(iv) Penassay broth. Duplicate open tubes of Penassay broth (Difco antibiotic medium 3 ) were inoculated, and growth and production of ammonia (Nessler reagent) were recorded at 11 days (Table 9, columns 8 and 9 ).

$\mathrm{H}_{2} \mathrm{~S}$ from cysteine. Tubes containing $0.01 \%$ cysteine hydrochloride (26), sterilized by filtration, in SA broth were inoculated with the test organisms. Dried strips of filter paper impregnated with a 5\% lead acetate solution were folded over the top of the tube, which was capped as usual. Blackening of the paper strip, owing to the formation of lead sulfide, indicated $\mathrm{H}_{2} \mathrm{~S}$ production (15), and this was noted at 7 days (Table 10, column 2).

Formation of indole. A small amount of Kovac reagent (26) was added to 14 - and 28 -day-old casein broth cultures and to 7- and 14-day-old Casitone broth cultures. After mixing and standing for up to $0.5 \mathrm{~h}$, a red colour at the interface indicated the formation of indole from tryptophan (Table 10, column 3). 

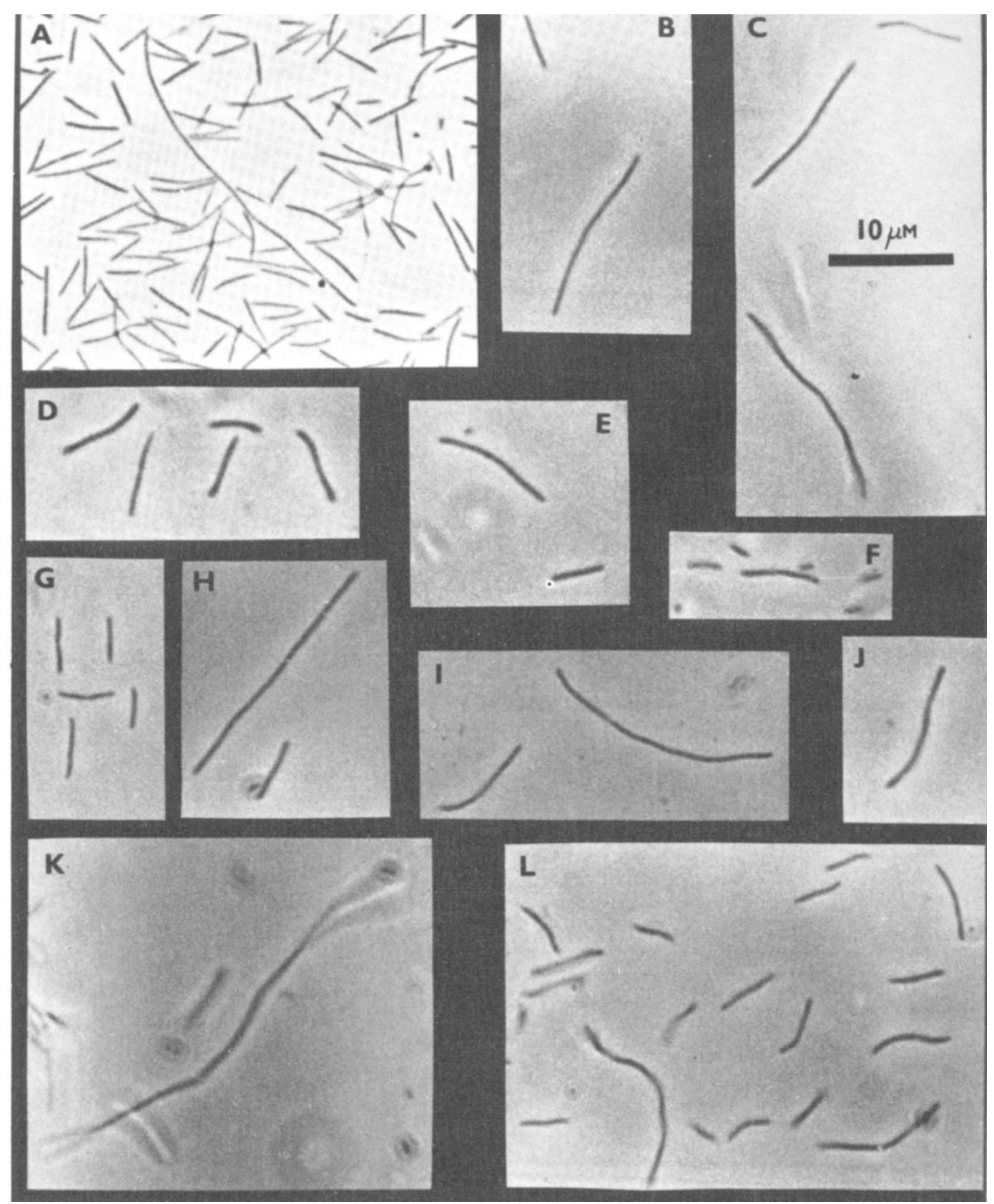

FIG. 1. Cells of Cytophaga johnsonae strains and Flavobacterium pectinovorum NCIB 9059. (A and B) ATCC 17061; (C) UASM 3; (D) UASM 4539; (E) UASM 4707; (F) UASM E-1-25; (G) UASM 4433; (H and K) NCIB 9059; (I) UASM 405; (J) UASM B-2-25; (L) UASM ALF. Media: (A) from the spreading edge of a 5 -day-old colony on yeast cell agar; $(B, C, D, E, H, J, K$, and $L)$ from 60-h-old skim acetate broth; ( $F$ and $G$ ) from 24-h-old skim acetate broth. All of these 10 strains had flexible cells which exhibited gliding motility.

Catalase production. After 5 days of incubation of streak cultures, SA plates were flooded with $10 \%$ hydrogen peroxide (26). Copious evolution of bubbles was evidence for catalase activity and hence an aerobic respiration (Table 10, column 4).
Oxidase production. A freshly prepared solution of $0.1 \mathrm{~g}$ of tetramethyl-para-phenylenediamine dihydrochloride in $10 \mathrm{ml}$ of distilled water (13) was allowed to stand for $15 \mathrm{~min}$ and then drops were placed on a piece of Whatman no. 1 filter paper. Test 
TABLE 11. DNA base ratios for Cytophaga johnsonae strains and Flavobacterium pectinovorum NCIB 9059

\begin{tabular}{lll}
\hline \multicolumn{1}{c}{ Strain } & \multicolumn{1}{c}{ Mol\% G+C } & \multicolumn{1}{c}{ Reference } \\
\hline C. johnsonae & & 19 \\
ATCC 17061 & 33 & 19 \\
UASM 405 & $\begin{array}{c}34.6\left(T_{m}\right)-35 \text { (buoy- } \\
\text { ant density) }\end{array}$ \\
UASM 405 & $30-32$ & M. Mandel, per- \\
& & sonal communi- \\
& & cation to F. D. \\
& & Cook \\
F. pectinovorum & & 21 \\
NCIB 9059 & 32.9 & 21 \\
NCIB 10021 & 32.7 & \\
\hline
\end{tabular}

colonies from various agar plates were smeared on the reagent-saturated paper. If oxidase was present, a dark purple colour developed within $10 \mathrm{~s} \mathrm{(2)} \mathrm{(Table}$ 10 , column 5).

Phosphatase production. A $20-\mathrm{ml}$ volume of a filter-sterilized $0.5 \%$ phenolphthalein diphosphoric acid solution was added to 1 litre of routine SA agar just before pouring plates, to give a final concentration of $0.1 \%$ (3). Cultures were spotted four per plate, and after 4 days of incubation the plates were exposed to ammonia vapour. Colonies producing sufficient phosphatase to liberate free phenolphthalein became bright pink; others were unchanged (Table 10 , column 6).

Nitrate reduction in anaerobic system. Duplicate tubes of Penassay broth (Difco antibiotic medium 3) containing $0.1 \% \mathrm{KNO}_{3}$ (1) were inoculated with the test organisms and incubated in Gas-Pak jars under hydrogen and carbon dioxide to test for reduction of $\mathrm{NO}_{3}{ }^{-}$to $\mathrm{NO}_{2}{ }^{-}$. Spot plate tests for ammonia production (Nessler reagent), $\mathrm{pH}$ (bromothymol blue), nitrate and nitrite (acidified diphenylamine), and nitrite (acidified Trommsdorf reagent), and a hot wire test for nitrogen gas bubbles were carried out at 11 days (Table 10, column 7). A similar series of tests was done with tubes containing $0.1 \% \mathrm{KNO}_{2}$ to test for the denitrification of $\mathrm{NO}_{2}^{-}$to a gas (Table 10 , column 8).

\section{RESULTS AND DISCUSSION}

No type culture has yet been designated for C. johnsonae. All of these isolates conformed to the published description of $C$. johnsonae (14, 29,30 ), except that ATCC 17061 and UASM 405 were not found to use $\mathrm{NO}_{3}{ }^{-}$as a nitrogen source, ATCC 17061 and UASM 4433 were sucrose negative, and UASM ALF utilized mannitol (P. J. Christensen, Ph.D. Thesis, University of Alberta, Edmonton, Alberta, Canada, 1973).

All of the 10 cultures examined were gramnegative, flexing rods which were arranged singly and showed gliding but not flagellar motility (Fig. 1). All showed thin, spreading, orangeyellow growth with no water-soluble pigment on Cook's cytophaga agar and skim acetate agar and were silky in broth culture. The morphological, physiological, and biochemical characteristics of $F$. pectinovorum NCIB 9059 were found to correspond closely to those of the nine $C$. johnsonae strains investigated (Tables 2 to 10 ). The deoxyribonucleic acid (DNA) base ratio of $33 \mathrm{~mol} \%$ guanine plus cytosine for NCIB 9059 falls in the centre of the reported range for $C$. johnsonae (Table 11). Another strain of $F$. pectinovorum, NCIB 10021, which is no longer available, was also reported to have a DNA base ratio within this range (Table 11).

The strain NCIB 9059 (ATCC 19366) has been rejected as a species of the genus Flavobacterium on account of its gliding motility (32), and several authors have remarked upon the similarity of the properties of this organism with those of the genus Cytophaga $(17,18,21$; O. B. Weeks, personal communication). The data reported above on a wide range of properties of strain NCIB 9059 suggest that this organism may be more properly classified as Cytophaga johnsonae Stanier 1947 (29). Since this strain was the holotypic culture of Flavobacterium pectinovorum Dorey 1959 (8), the latter name is considered to be a junior subjective synonym.

\section{ACKNOWLEDGMENTS}

I am indebted to F. D.Cook for helpful discussion and friendly counsel, and thanks go to D. C. Gillespie for the gift of two cultures and to $M$. Mandel for determining the guanine-plus-cytosine content of the DNA of strain UASM 405. The financial assistance of the National Research Council of Canada is gratefully acknowledged.

\section{LITERATURE CITED}

1. Allen, O. N. 1959. Experiments in soil bacteriology. Burgess, Minneapolis.

2. Bailey, W. R., and E. G. Scott. 1970. Diagnostic microbiology, 3rd ed. Mosby, St. Louis.

3. Barber, M., and S. W. A. Kuper. 1951. Identification of Staphylococcus pyogenes by the phosphatase reaction. J. Pathol. Bacteriol. 63:65-68.

4. Board, R. G., and A. J. Holding. 1960. The utilization of glucose by aerobic Gram negative bacteria. J. Appl. Bacteriol. 23:xi-xii.

5. Brisou, J. 1958. Etude de quelques Pseudomonadaceae. Baillet, Bordeaux.

6. Christensen, P. J. 1974. A new approach to the description of colony colour of cytophagas and their allies. Can. J. Microbiol. 20:937-942.

7. Christensen, P. J., and F. D. Cook. 1972. The isolation and enumeration of cytophagas. Can. J. Microbiol. 18:1933-1940.

8. Dorey, M. J. 1959. Some properties of a pectolytic soil Flavobacterium. J. Gen. Microbiol. 20:91-104.

9. Emerson, J. E., and O. L. Weiser. 1963. Detecting cellulose-digesting bacteria. J. Bacteriol. 86:891-892.

10. Gran, H. H. 1902. Studien über Meeresbakterien. II. Uber die Hydrolyse des Agar-Agars durch ein neues Enzym, die Gelase. Bergens Museums Aarbog 1902, no. 2.

11. Gray, T. R. G., and T. F. Bell. 1963. The decomposition of chitin in an acid soil, p. 222-230. In J. Doeksen and J. Van der Drift (ed.), Soil organisms. North-Holland Publishing Co., Amsterdam. 
12. Hutchinson, H. B., and J. Clayton. 1919. The decomposition of cellulose by an aerobic organism (Spirochaeta cytophaga n. sp.). J. Agric. Sci. 9:143-173.

13. Kovacs, N. 1956. Identification of Pseudomonas pyocyanea by the oxidase reaction. Nature (London) 178:703-703.

14. Leadbetter, E. R. 1974. Cytophagales, p. 99-127. In R. E. Buchanan and N. E. Gibbons (ed.), Bergey's manual of determinative bacteriology, 8 th ed. Williams and Wilkins Co., Baltimore.

15. Lewin, R. A., and D. M. Lounsbery. 1969. Isolation, cultivation and characterization of flexibacteria. $J$. Gen. Microbiol. 58:145-170.

16. Lingappa, Y., and J. L. Lockwood. 1961. A chitin medium for isolation, growth and maintenance of Actinomycetes. Nature (London) 189:158-158.

17. Lund, B. M. 1969. Properties of some pectolytic, yellow pigmented, gram-negative bacteria isolated from fresh cauliflowers. J. Appl. Bacteriol. 32:60-67.

18. McMeekin, T. A., J. T. Patterson, and J. G. Murray. 1971. An initial approach to the taxonomy of some gram negative, yellow pigmented rods. J. Appl. Bacteriol. 34:699-716.

19. Mandel, M., and E. R. Leadbetter. 1965. Deoxyribonucleic acid base composition of myxobacteria. J. Bacteriol. 90:1795-1796.

20. Mann, S. O. 1968. An improved method for determining cellulolytic activity in anaerobic bacteria. J. Appl. Bacteriol. 31:241-244.

21. Mitchell, T. G., M. S. Hendrie, and J. M. Shewan. 1969. The taxonomy, differentiation and identification of Cytophaga species. J. Appl. Bacteriol. 32:40-50.

22. Munsell Color Co. The Munsell book of color. Munsell
Color Co. Inc., Baltimore.

23. Perry, I. B. 1973. Gliding motility in some non-spreading flexibacteria. J. Appl. Bacteriol. 36:227-232.

24. Reynolds, D. M. 1954. Exocellular chitinase from a Streptomyces sp. J. Gen. Microbiol. 11:150-159.

25. Skerman, V. B. D. 1967. A guide to the identification of the genera of bacteria, 2nd ed. Williams and Wilkins Co., Baltimore.

26. Society of American Bacteriologists. 1957. Manual of microbiological methods. McGraw-Hill, Toronto.

27. Stanier, R. Y. 1941. Studies on marine agar-digesting bacteria. J. Bacteriol. 42:527-559.

28. Stanier, R. Y. 1942. The Cytophaga group; a contribution to the biology of myxobacteria. Bacteriol. Rev. 6:143-196.

29. Stanier, R. Y. 1947. Studies on non-fruiting myxobacteria. I. Cytophaga johnsonae n.sp., a chitin-decomposing myxobacterium. J. Bacteriol. 53:297-315.

30. Stanier, R. Y. 1959. Myxobacterales Jahn, p. 854-891. In R. S. Breed, E. G. D. Murray, and N. R. Smith (ed.), Bergey's manual of determinative bacteriology, 7th ed. Williams and Wilkins Co., Baltimore.

31. Veldkamp, H. 1961. A study of two marine, agar-decomposing, facultatively anaerobic myxobacteria. J. Gen. Microbiol. 26:331-342.

32. Weeks, O. B. 1974. Genus Flavobacterium, p. 357-364. In R. E. Buchanan and N. E. Gibbons (ed.), Bergey's manual of determinative bacteriology, 8th ed. Williams and Wilkins Co., Baltimore.

33. Zvirbulis, E., and H. D. Hatt. 1969. Status of names of bacterial taxa not evaluated in Index Bergeyana (1966). Addendum III. Achromobacter to Lactobacterium. Int. J. Syst. Bacteriol. 19:309-370. 